\section{Auxin Type, Auxin Concentration, and Air and Substrate Temperature Difference Play Key Roles in the Rooting of Juvenile Hardwood Pecan Cuttings}

\author{
Ji-Yu Zhang ${ }^{1,5}$, Zhong-Ren Guo ${ }^{1}$, Rui Zhang ${ }^{3}$, Yong-Rong $\mathrm{Li}^{2,5}$, \\ Lin $\mathrm{CaO}^{3}$, You-Wang Liang ${ }^{3}$, and Li-Bin Huang ${ }^{4}$
}

AdDITIONAL INDEX wORDs. Carya illinoinensis, vegetative propagation, adventitious root formation

Summary. This study examined the ability to vegetatively propagate 1 -year-old pecan (Carya illinoinensis) through the rooting of hardwood cuttings. Cuttings were treated with varying concentrations of different auxins and different combinations of media and ambient temperatures. Under different temperature conditions, all auxin treatments induced the rooting of cuttings but did not promote sprouting. The effectiveness of the induction of adventitious roots was as follows: 1 -naphthalene acetic acid (NAA) $>$ indole 3 -butyric acid $>$ indole 3 -acetic acid. The base of the parent shoot treated by NAA at a concentration of $0.09 \%$, planted in substrate with bottom heat was the most effective, with $82 \%$ rooting, 8.3 roots / cutting and root lengths of $7.3 \mathrm{~cm}$. These findings suggested that auxin and substrate/air temperature differences are both indispensable in the process of adventitious roots formation in pecan. This study revealed that the propagation of hardwood cuttings derived from branches of 1 -year-old pecan is possible.

$\mathrm{P}$ ecan is a medium to large, deciduous, monoecious tree and most cultivars are propagated on seedling pecan rootstocks by the patch bud in the summer in China. Pecan seeds are expensive ( $\$ 0.17$ to $\$ 0.34$ each), contributing to the high cost of pecan trees.

One-year-old pecan seedlings with trunk diameters exceeding $0.6 \mathrm{~cm}$ are used as the rootstocks. Trees are patch budded $\approx 10$ to $15 \mathrm{~cm}$ above the soil line. The portion of the rootstock above the patch bud site is removed during dormancy to force the patch bud in the spring. The seedling rootstock top normally is discarded when removed to force the patch bud, but it might be used to produce additional rootstocks if successfully rooted.

This work was supported by grants from the Forestry Industry Research Special Funds for Public Welfare Project No. 201304711 and the Central Government Forestry Science and Technology Demonstration Project No. (2012) TK28.

${ }^{1}$ Institute of Botany, Jiangsu Province and the Chinese Academy of Sciences, Nanjing 210014, China

${ }^{2}$ Nanjing Green Universe Pecan Science and Technology Co. Ltd., Nanjing 210007, China

${ }^{3}$ College of Forest Resources and Environment, Nanjing Forestry University, Nanjing 210037, China

${ }^{4}$ Jiangsu Academy of Forestry, Nanjing 211153, China ${ }^{5}$ Corresponding author. E-mail: maxzhangjy@163.com or11194288@163.com.
Successful rooting would make full use of resources that were otherwise discarded. Propagation material could be increased by 2 - to 3 -fold annually since many of the rootstocks were branched above the patch bud. Pecan has been propagated by tissue culture (Lazarte, 1984; Obeidy, 1993), leafy stem cuttings (Youssef, 1993), and mound layering (Wood and Byron, 1989), but commercially acceptable propagation of juvenile cuttings has not yet been demonstrated. This study was undertaken to investigate the rooting of hardwood cuttings from l-year-old rootstock treated with varying concentrations of selected auxins and different combinations of media and air temperatures.

\section{Materials and methods}

Plant materials. Pecan seeds were harvested at maturity in Oct. 2012 and planted in Feb. 2013 in a greenhouse at the Nanjing Green Universe Pecan Science \& Technology
Co. Ltd., Nanjing, China. Seedlings were transplanted to the field in May 2013 and irrigated every $10 \mathrm{~d}$ using furrow irrigation to ensure that the soil had been wetted to the full depth of rooting of the seedlings. Trees were fertilized in July and again in August using a broadcast application of $20 \mathrm{lb} /$ acre nitrogen (Kingenta Ecological Engineering Group, Jinan, China). 'Pawnee' pecan was patch budded $10 \mathrm{~cm}$ above the ground in Aug. 2013 on to 6-month-old seedlings. The rootstocks were pruned $\approx 2 \mathrm{~cm}$ above the patch bud in Feb. 2014 while the trees were dormant. The pruned rootstock tops were used as hardwood cuttings.

Hardwood CutTing. Hardwood cuttings collected from the basal portion of the pruned rootstock top in Feb. 2014 were trimmed to $12 \mathrm{~cm}$ long. Auxin [1-naphthalene acetic acid (NAA), indole 3-butyric acid (IBA), and indole 3-acetic acid (IAA)] powders (Sigma-Aldrich, Shanghai, China) were dissolved in a small amount of ethanol (analytical reagent, content $\geq 99.7$ ), and then diluted to the appropriate concentration using water. Rooting substrate was purchased from Liaoning Province Jade Source Peat Development Co., Qingyuan, China. The rooting substrate contained peat, perlite, coarse sand and silver sand in the ratio $2: 4: 1: 1$

The basal ends $(2-3 \mathrm{~cm})$ of each cutting were soaked in distilled water (for the control) or in selected concentrations of hormones at room temperature for $4 \mathrm{~h}$. Solutions were $0.03 \%, 0.06 \%$, and $0.09 \%$ of IAA or IBA, and $0.06 \%, 0.09 \%$, and $0.12 \%$ of NAA. Cuttings were then planted into the root substrate with selected media/ambient temperatures in three climate-controlled plastic greenhouses in Feb. 2014 with light intensity 20,000 to $40,000 \mathrm{~lx}$. The media/ ambient temperatures were as follows: 1) media temperature and the ambient temperatures were both at $13 \pm 2{ }^{\circ} \mathrm{C} ; 2$ ) electric heating cables were placed at the bottom of rooting substrates for heat, the temperature at

\begin{tabular}{llll}
\hline $\begin{array}{l}\text { Units } \\
\begin{array}{l}\text { To convert U.S. to SI, } \\
\text { multiply by }\end{array}\end{array}$ & U.S. unit & SI unit & $\begin{array}{l}\text { To convert SI to U.S., } \\
\text { multiply by }\end{array}$ \\
\hline 10.7639 & $\mathrm{fc}$ & $\mathrm{lx}$ & 0.0929 \\
2.54 & inch $(\mathrm{es})$ & $\mathrm{cm}$ & 0.3937 \\
1.1209 & $\mathrm{lb} / \mathrm{acre}$ & $\mathrm{kg} \cdot \mathrm{ha}^{-1}$ & 0.8922 \\
$\left({ }^{\circ} \mathrm{F}-32\right) \div 1.8$ & ${ }^{\circ} \mathrm{F}$ & ${ }^{\circ} \mathrm{C}$ & $\left({ }^{\circ} \mathrm{C} \times 1.8\right)+32$
\end{tabular}


the base of cuttings was $25 \pm 2{ }^{\circ} \mathrm{C}$, and the external air temperature was $13 \pm 2{ }^{\circ} \mathrm{C}$; and 3 ) the media and ambient temperatures were both maintained at $25 \pm 2{ }^{\circ} \mathrm{C}$. Cuttings were irrigated with sprinklers every $5 \mathrm{~d}$ to make sure that the relative humidity remained $\approx 60 \%$. Soil thermometers (i500-TWS; Zhi Tuo Instrument Co., Hangzhou, China) were inserted into the media to record substrate temperatures every day, and glass stem sealed thermometers (Zhi Tuo Instrument Co.) were placed in ambient conditions to control the temperatures.

An additional experiment was set up to examine the effect of parent shoot position on adventitious root formation. Cuttings were taken from different positions of the 1-year-old rootstock (base 15 to $55 \mathrm{~cm}$ off the ground, middle 56 to $95 \mathrm{~cm}$ off the ground). The upper portion was discarded because it was very thin. Cuttings were treated with $0.06 \%$ IBA or $0.09 \%$ NAA, respectively, and set in rooting substrate with the temperature at the base of cuttings was $25 \pm$ $2{ }^{\circ} \mathrm{C}$ and the external air temperature was $13 \pm 2{ }^{\circ} \mathrm{C}$.

DATA COLLECTION AND STATISTICAL ANALYSES. A split-plot experimental design was used with differing media and ambient temperature as the main plot and differing auxin types and auxin concentrations equally randomized as the subplot with three replications containing 20 cuttings, and repeated three times. After $35 \mathrm{~d}$, the cuttings were evaluated for adventitious rhizogenesis: 1 ) rooting percentage, 2) number of roots per rooted cutting, and 3 ) average root length. To test significant differences of this experiment, data were subjected to analysis of variance and Duncan's multiple range tests at $P<0.05$ using the SPSS Grad Pack 16 computer program (IBM Corp., Armonk, NY).

\section{Results and discussion}

When the medium and the ambient temperatures were $13 \pm 2{ }^{\circ} \mathrm{C}$, adventitious roots did not develop, although cuttings were treated with various auxins (Table 1 ). When the medium and ambient temperatures were both $25{ }^{\circ} \mathrm{C}$, cuttings developed sprouts rapidly, but did not develop adventitious roots with any auxin type and concentration. However, the rooting percentages of cuttings treated with auxins were greater when the temperature at the base of cuttings was $25 \pm 2{ }^{\circ} \mathrm{C}$ and the ambient temperature was $13 \pm 2{ }^{\circ} \mathrm{C}$. It has been reported that factors like genetic potential, origin of cutting, type of hormone, age of the mother plant, season of collection, stock plant physiology, and propagation environment play significant role in the successful formation of adventitious roots (Kibbler et al., 2004; Leakey, 2004). Xi (1995) reported that the suitable soil temperatures for the formation of adventitious roots were 15 to $20{ }^{\circ} \mathrm{C}$ for grape (Vitis vinifera) and cherry (Prunus cerasum and P. cerasus) which was 3 to $5{ }^{\circ} \mathrm{C}$ higher than the air temperatures. Cuttings would first develop adventitious roots and then sprouts as a result of the balance between water absorption in roots and water consumption aboveground (Xi, 1995). However, the response to soil temperature varies among species (Xi, 1995). The suitable soil temperature for rooting was 20 to $25^{\circ} \mathrm{C}$ for grape and $15{ }^{\circ} \mathrm{C}$ for cherry $(\mathrm{Xi}$, 1995). In our assay, the difference between substrate $\left(25 \pm 2{ }^{\circ} \mathrm{C}\right)$ and air $\left(13 \pm 2{ }^{\circ} \mathrm{C}\right)$ temperatures appeared to be critical to the successful formation of adventitious roots in pecan.

The cuttings without any auxins treatment (control) did not develop adventitious roots, although they were planted in root substrate with bottom heat, suggesting that auxins were effective in promoting rooting of hardwood pecan cuttings. The adventitious rhizogenous response varied in the cuttings treated with varying concentrations of different auxins. There were significant differences $(P<0.05)$ among the three auxin treatments (NAA $>$ IBA $>$ IAA). The rooting percentage was strongly determined by the type of auxin (Table 1). Among treatments, cuttings dipped in $0.09 \%$ NAA solution showed the greatest rooting percentage $(82 \%)$ and a relatively high rooting percentage $(80 \%)$ was found in cuttings with $0.06 \%$ IBA (Table 1 ). NAA at $0.09 \%$ was also found to enhance the number of roots and root length (Fig. 1; Table 1). The rooting percentage, number of roots and length of roots per cutting all increased rapidly at lower concentrations of NAA and NAA up to a maximum of $0.09 \%$. However, with increased hormone concentrations $(0.12 \%)$, these values decreased (Fig. 1; Table 1). Similar rooting responses were observed with IAA and IBA hormonal treatments (Table 1 ). These results suggested that exogenously applied hormones play an important role in adventitious rhizogenesis in pecan. As a result, the best concentration for rapid rhizogenesis was considered to be $0.09 \%$ of NAA. The rooted hardwood cuttings were successfully transplanted to the experimental field after $45 \mathrm{~d}$ of hormonal treatment.

Synthetic auxins have a strong promotional role in stimulating adventitious rooting of hardwood cuttings of tree species (Kesari et al., 2009; Stefancic et al., 2005; Tchoundjeu et al., 2004; Wang et al., 2005). It has been reported that auxins play an important role in forming the adventitious roots in wood, and exogenous and endogenous levels of auxins affect the divisions of the first root (Kochhar et al., 2005; Ludwig-Müller, 2000). Auxin application have been found to enhance the rate of adventitious root development and increase the number of roots initiated per rooted cutting in a variety of species (Exadaktylou et al., 2009; Kesari et al., 2009; Palanisamy et al., 1998).

The optimal auxin type and concentration for rooting of hardwood cuttings varies among species (Exadaktylou et al., 2009; Pirlak, 2000; Rosier et al., 2004; Tsipouridis et al., 2005). Synthetic IBA had a strong promotional effect on the rooting of cuttings of the 'Gisela 5' cherry rootstock (P. cerasus $\times$ Prunus canescens) (Stefancic et al., 2005; Wang et al., 2005 ) and the best concentration of IBA was shown to be $1000 \mathrm{mg} \cdot \mathrm{L}^{-1}$ (Exadaktylou et al., 2009). Kesari et al. (2009) reported that IAA, IBA and NAA treatments enhanced the rooting of cuttings of millettia pinnate (Pongamia pinnata), and the best concentration for rapid rhizogenesis was $4.92 \mathrm{~mm}$ of IBA. The rooting percentage, number of roots and length of roots per cuttings was highest at $0.09 \%$ of NAA in pecan. However, these results decreased with an increase in any hormone concentration levels. It is important to note that in this study the dosage of hormone was a key factor in the induction of rooting. Similar results have also been found for hardwood cuttings of millettia pinnate (Kesari 
Table 1. Effect of auxin types and temperature difference on rooting of 1-year-old hardwood cuttings of pecan. Experiments were carried out in three air-conditioned plastic covered greenhouses in Feb. 2014 with light intensity 20,000-40,000 lx $(1858.0-3716.0 \mathrm{fc})$. Data were recorded after $35 \mathrm{~d}$ of planting. Each mean is based on three replicates, each of which consisted of 20 cuttings.

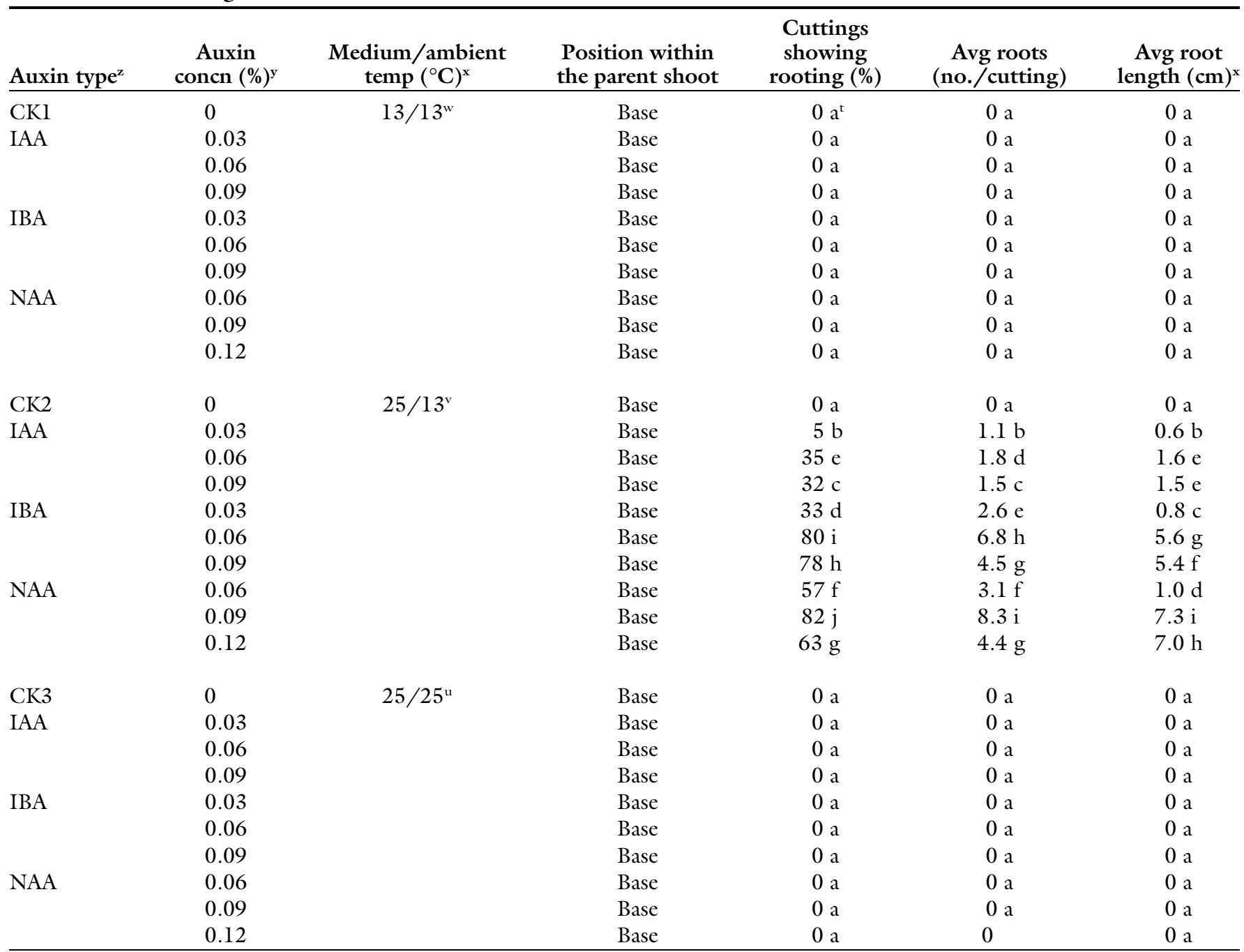

${ }^{2} \mathrm{IAA}=$ indole 3 -acetic acid, $\mathrm{IBA}=$ indole 3 -butyric acid, $\mathrm{NAA}=1$-naphthalene acetic acid, $\mathrm{CK} 1=$ control 1 ; CK2 = control 2 , CK3 = control 3 .

yercent weight in volume.

${ }^{\mathrm{x}}\left(1.8 \times{ }^{\circ} \mathrm{C}\right)+32={ }^{\circ} \mathrm{F}, \mathrm{l} \mathrm{cm}=0.3937$ inch.

"Media temperature and the ambient temperatures were both $13 \pm 2{ }^{\circ} \mathrm{C}$.

vElectric heating cables were placed at the bottom of rooting substrates for heat, and the temperature at the base of cuttings was $25 \pm 2{ }^{\circ} \mathrm{C}$ and the external air temperature was $13 \pm 2{ }^{\circ} \mathrm{C}$.

uThe media and ambient temperatures were both maintained at $25 \pm 2{ }^{\circ} \mathrm{C}$.

'Values in the same column followed by the same letter are not significantly different via Duncan's multiple range tests at $P<0.05$.

et al., 2009), 'Gisela 5' cherry rootstocks (Exadaktylou et al., 2009), and yohimbe [Pausinystalia johimbe (Tchoundjeu et al., 2004)].

In this article, we selected the base and middle portions of the shoots from l-year-old pecan rootstock trees, while the upper portion was discarded. The results showed that cuttings collected from the base of the parent shoots had better rooting than the middle, regardless of whether treated with $0.06 \%$ IBA or $0.09 \%$ NAA (Table 2). Juvenility of cuttings plays a key role in rooting and the position of the cuttings on the parent shoots affects the rooting of hardwood cuttings (Hartmann et al., 2002; Smith and Chiu, 1980). Keeley et al. (2004) reported that hardwood cuttings taken from more basal or middle cane segments of the 'Norton' grapevine rootstock (Vitis aestivalis) rooted better than cuttings from the apical region (Keeley et al., 2004). Hardwood cuttings of american sycamore (Platanus occidentalis) obtained from the base shoot showed the best rooting (Abdullah et al., 1988). Exadaktylou et al. (2009) reported that the highest rooting percentage was found on cuttings taken from the base or the upper region of shoots on 15 Nov. or 2 Mar. and cuttings taken on 1 Dec. from the middle of the shoots (Exadaktylou et al., 2009).

\section{Conclusions}

Rapid rhizogenesis occurred when cuttings were treated with $0.09 \%$ NAA with substrate temperatures of $25 \pm 2{ }^{\circ} \mathrm{C}$ and air temperatures of $13 \pm 2{ }^{\circ} \mathrm{C}$. The results of this study showed that adventitious 
A

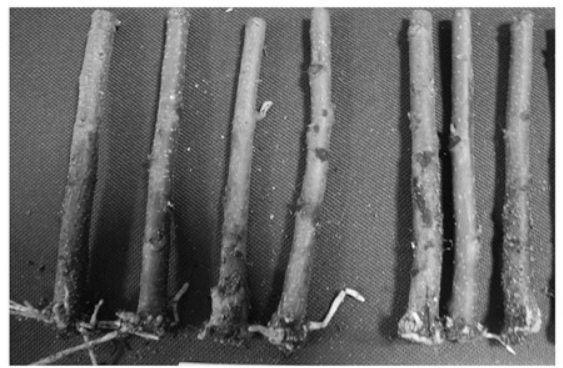

C

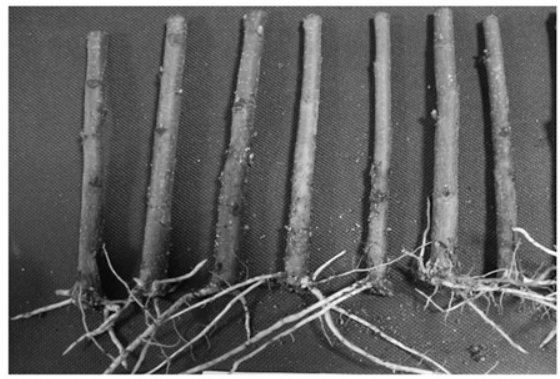

$\mathbf{E}$

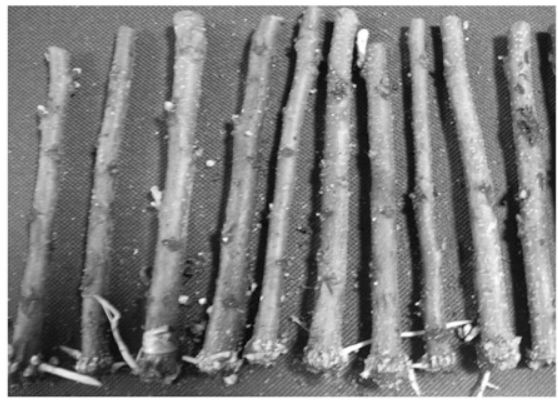

Fig. 1. Adventitious root formation of pecan hardwood cuttings planted in substrate with bottom heat treated with auxins. Electric heating cables were placed at the bottom of rooting substrates for heat, and the temperature at the base of cuttings was maintained at $25 \pm 2{ }^{\circ} \mathrm{C}$ and the external temperature was $13 \pm 2{ }^{\circ} \mathrm{C}\left[\left(1.8 \times{ }^{\circ} \mathrm{C}\right)+\right.$ $\left.32={ }^{\circ} \mathrm{F}\right]$. (A) $0.06 \% 1$-naphthalene acetic acid (NAA), (B) $0.09 \% \mathrm{NAA}$, (C) $0.12 \%$ NAA, (D) $0.06 \%$ indole 3 -butyric acid (IBA), and (E) $0.06 \%$ indole 3 -acetic acid (IAA). Experiment was carried out in an air-conditioned plastic covered greenhouse in Feb. 2014 with light intensity 20,000-40,000 lx (1858.0-3716.0 fc).

Table 2. Effect of cutting position within the parent shoots on rooting of 1-yearold hardwood cuttings of pecan. Experiment was carried out in an air conditioned plastic covered greenhouse in Feb. 2014 with light intensity 20,000-40,000 $\mathrm{lx}(1858.0-3716.0 \mathrm{fc})$. Electric heating cables were placed at the bottom of rooting substrates for heat, and the temperature at the base of cuttings was maintained at $25 \pm 2{ }^{\circ} \mathrm{C}$ and the external temperature was $13 \pm 2{ }^{\circ} \mathrm{C}[(1.8 \times$ $\left.\left.{ }^{\circ} \mathrm{C}\right)+32={ }^{\circ} \mathrm{F}\right]$. Data were recorded after 35 d of planting. Each mean is based on three replicates, each of which consisted of 20 cuttings.

\begin{tabular}{lcccc}
\hline Treatment $^{\mathrm{z}}$ & $\begin{array}{c}\text { Position within } \\
\text { the parent shoot }\end{array}$ & $\begin{array}{c}\text { Cuttings showing } \\
\text { rooting (\%) }\end{array}$ & $\begin{array}{c}\text { Avg roots } \\
(\text { no./cutting) }\end{array}$ & $\begin{array}{c}\text { Avg root } \\
\text { length }(\mathrm{cm})^{\mathrm{y}}\end{array}$ \\
\hline IBA $0.06 \%$ & Middle & $77 \mathrm{a}^{\mathrm{x}}$ & $5.7 \mathrm{a}$ & $4.3 \mathrm{a}$ \\
& Base & $80 \mathrm{~b}$ & $6.8 \mathrm{~b}$ & $5.6 \mathrm{~b}$ \\
NAA 0.09\% & Middle & $70 \mathrm{a}$ & $6.2 \mathrm{a}$ & $5.6 \mathrm{a}$ \\
& Base & $82 \mathrm{~b}$ & $8.3 \mathrm{~b}$ & $7.3 \mathrm{~b}$ \\
\hline
\end{tabular}

${ }^{\mathrm{z}}$ Auxins concentration was percent weight in volume; IBA = indole 3 -butyric acid, NAA = 1-naphthalene acetic acid ${ }^{\mathrm{y}} 1 \mathrm{~cm}=0.3937$ inch

'Values in the same column followed by the same letter are not significantly different via Duncan's multiple range tests at $P<0.05$. rhizogenesis of hardwood cuttings of pecan in response to the exogenous application of growth hormones and different substrates and air temperatures provides a new method that improves vegetative propagation, and pecan has the value of using the waste material from budding to increase plant numbers by using the cuttings that are normally discarded. This report offers a feasible and less demanding method for the vegetative propagation of pecan, and its commercialization in areas that are suitable for its growth.

\section{Literature cited}

Abdullah, Y., M. Abdullah, and J. Al-Ashoo. 1988. Effect of tree age, cutting length and their distance from the base of shoots on the propagation of Platanus occidentalis L. seedlings. Mesopotamia J. Agr. 20:221236.

Exadaktylou, E., T. Thomidis, B. Grout, G. Zakynthinos, and C. Tsipouridis. 2009. Methods to improve the rooting of hardwood cuttings of the 'Gisela 5 ' cherry rootstock. HortTechnology 19:254-259.

Hartmann, H., D. Kester, F. Davies, and R. Geneve. 2002. Hartmann and Kesters' plant propagation: Principles and practices. 7th ed. Prentice Hall, Upper Saddle River, NJ.

Keeley, K., J.E. Preece, B.H. Taylor, and I. Dami. 2004. Effects of high auxin concentrations, cold storage, and cane position on improved rooting of Vitis aestivalis Michx. Norton cuttings. Amer. J. Enol. Viticult. 55:265-268.

Kesari, V., A. Krishnamachari, and L. Rangan. 2009. Effect of auxins on adventitious rooting from stem cuttings of candidate plus tree Pongamia pinnata (L.), a potential biodiesel plant. Trees (Berl.) 23:597-604.

Kibbler, H., M. Johnston, and R. Williams. 2004. Adventitious root formation in cuttings of Backhousia citriodora F. Muell: 1 . Plant genotype, juvenility and characteristics of cuttings. Sci. Hort. 102:133-143.

Kochhar, S., V. Kochhar, S. Singh, R. Katiyar, and P. Pushpangadan. 2005. Differential rooting and sprouting behaviour of two Jatropha species and associated physiological and biochemical changes. Curr. Sci. 89:936-939.

Lazarte, J.E. 1984. Propagating pecan rootstock by tissue culture. Amer. Nurseryman 159:79-82.

Leakey, R.R. 2004. Physiology of vegetative reproduction, p. 1655-1668. In: J. 
Burley, E. Evans, and J.A. Younquist (eds.). Encyclopaedia of forest sciences. Academic Press, London, UK.

Ludwig-Müller, J. 2000. Indole-3-butyric acid in plant growth and development. Plant Growth Regulat. 32:219-230.

Obeidy, A.A. 1993. Organogenesis from mature pecan cotyledons and embryonic axes. HortScience 28:213-215.

Palanisamy, K., S. Ansari, P. Kumar, and B. Gupta. 1998. Adventitious rooting in shoot cuttings of Azadirachta indica and Pongamia pinnata. New For. 16:81-88.

Pirlak, L. 2000. Effects of different cutting times and IBA doses on the rooting rate of hardwood cuttings of cornelian cherry (Cornus mas L.). Anadolu 10:122134.

Rosier, C.L., J. Frampton, B. Goldfarb, F. A. Blazich, and F.C. Wise. 2004. Growth stage, auxin type, and concentration influence rooting of stem cuttings of fraser fir. HortScience 39:1397-1402.

Smith, M.W. and H. Chiu. 1980. Seasonal changes in the rooting of juvenile and adult pecan cuttings. HortScience 15:594-595.

Stefancic, M., F. Stampar, and G. Osterc. 2005. Influence of IAA and IBA on root development and quality of Prunus 'Gisela 5' leafy cuttings. HortScience 40:2052-2055.

Tchoundjeu, Z., M.-L. Ngo Mpeck, E. Asaah, and A. Amougou. 2004. The role of vegetative propagation in the domestication of Pausinystalia jobimbe (K. Schum), a highly threatened medicinal species of west and central Africa. For. Ecol. Mgt. 188:175-183.
Tsipouridis, C., A. Isaakidis, A. Manganaris, I. Therios, and Z. Michailidis. 2005. Propagation and field performance of own-rooted peach trees. Anim. Prod. Sci. 44:1225-1229.

Wang, G., H. Wu, D. Su, and J. Na. 2005. Effects of NAA and IBA on biochemical metabolism and rooting of cherry (Prunus pseudocerasus Colt) cuttings. Acta Hort. Sinica 32:691-694.

Wood, B.W. and G. Byron. 1989. Clonal propagation of pecan by mound layering. HortScience 24:260-262.

Xi, R.T. 1995. Pomology. China Agriculture Press, Beijing, China.

Youssef, N. 1993. Use of ethephon for rooting of pecan leafy stem cuttings. Northern Nut Growers Assn. Annu. Rpt. 84:148-155. 